\title{
Tools of Labor Productivity Management at Agricultural Enterprises
}

\author{
Anastasia Sharopatova \\ Institute of Economics and Management of Agro-Industrial \\ Complex \\ Krasnoyarsk State Agrarian University \\ Krasnoyarsk, Russia \\ sharopatova@yandex.ru
}

\author{
Julia Olentsova \\ Krasnoyarsk State Agrarian University \\ Krasnoyarsk, Russia \\ tutor.eng@yandex.ru
}

\begin{abstract}
The article is devoted to the consideration of labor productivity tools. At the current stage of economic development, the problem of increasing labor productivity and efficiency of labor resources use at agricultural enterprises is of great importance. The factors determining the level and dynamics of labor productivity growth in agriculture are identified and the main components of the assessment and classification of factors affecting the change in labor productivity are presented. The analysis of the current state of labor productivity at agricultural enterprises in the region showed that the main reserve of its growth is to increase the stock, which requires the introduction of new technologies, varieties of zoned crops, livestock breeds and equipment in the production process.
\end{abstract}

Keywords: tools of labor productivity management, labor productivity factors, components of labor productivity assessment, analysis

\section{INTRODUCTION}

The basis of material and social well-being of society can be considered a highly efficient agricultural sector. It is no accident that agricultural production is a priority industry in absolutely all developed countries of the world. The development of the agricultural sector ensures the food security of our country, as well as the receiving of proven, high-quality products, which is important for the life and health of our population.

At the current stage of economic development, the problem of increasing labor productivity and efficiency of labor resources at agricultural enterprises is of great importance, since in the conditions of market relations strong competition between enterprises is inevitable, which pushes them to improve constantly the quality of their products and reduce production costs [1]. Labor productivity in Russia is up to 30 times lower than the level of the European Union and the United States; such data are provided in the ministry of economic development of the Russian Federation. In the middle of the last century, productivity in Japan was 10 times lower than in the United States, and they are now the undoubted leaders [2]. It can be noted that increasing the level of labor productivity is the main basis of economic growth and progress.

The aim of the study is to identify the tools of labor productivity management and factors that determine the level and dynamics of its growth in agriculture, as a set of driving forces and reasons by which there is a conscious and purposeful impact on the productivity of labor.

\section{MethodS AND RESUlts}

A set of economic methods: monographic, analytical, economic and statistical was applied to solve the tasks of the study. Identification of factors determining the level and dynamics of labor productivity growth in agriculture was carried out on the basis of the study of static material and conceptual documents for agricultural development in the region. Confirmation of the conclusions and results of the study was carried out on the basis of the study of practical provisions and recommendations presented in modern works of domestic and foreign scientists on the problems of increasing productivity. As a result of achieving the research objectives, management tools, productivity were identified, cost parameters were considered for the assessment, the growth rates of productivity and wages in agricultural enterprises and ways of increasing productivity were determined.

There are several categories of productivity management tools - legal, organizational, economic, motivational.

Legal tools guarantee the regulation of legal relations between management subjects. The main task of the legal tool is to prevent the number of contradictions from the legal relations of the participants in the management process and to provide them with optimal content [3] 
TABLE I.

TYPES OF STRATEGIES FOR THE ENTERPRISES OF THE AGRO-INDUSTRIAL COMPLEX

\begin{tabular}{|c|c|c|c|c|c|c|c|c|}
\hline \multirow[t]{3}{*}{ Indicators } & \multicolumn{3}{|c|}{ Aban district } & \multirow{3}{*}{$\begin{array}{l}2017 \text { to } \\
2015, \%\end{array}$} & \multicolumn{3}{|c|}{ JSC «Molokanovka» } & \multirow{3}{*}{$\begin{array}{l}2017 \text { to } \\
2015, \%\end{array}$} \\
\hline & \multicolumn{3}{|c|}{ Year } & & \multicolumn{3}{|c|}{ Year } & \\
\hline & 2015 & 2016 & 2017 & & 2015 & 2016 & 2017 & \\
\hline Number of employees, people & 382 & 302 & 285 & 74.6 & 55 & 48 & 46 & 83.6 \\
\hline Worked by workers employed in all industries - total: & & & & & & & & \\
\hline a) thousand people - days & 104 & 86 & 85 & 81.7 & 16 & 12 & 13 & 81.3 \\
\hline b) thousand people - hours & 739 & 645 & 593 & 80.2 & 128 & 126 & 127 & 99.2 \\
\hline Revenue from sales of agricultural products, mln. rub & 422.3 & 444.4 & 426.9 & 101.1 & 38.6 & 60.8 & 35.1 & 90.8 \\
\hline $\begin{array}{l}\text { Agricultural products produced: } \\
\text { - per } 1 \text { employee, thousand rubles }\end{array}$ & 1106 & 1471 & 1498 & 135.5 & 703 & 1266 & 763 & 60.3 \\
\hline - per 1 person - day, thousand rubles & 4061 & 5167 & 5022 & 123.7 & 2416 & 5064 & 2699 & 53.3 \\
\hline - per 1 person - hour, rub & 571.5 & 688.9 & 719.8 & 125.9 & 302 & 482 & 276 & 57.3 \\
\hline
\end{tabular}

TAble II. Growth Rates Of Productivity AND Wages In Agricultural ENTERPRises Of Aban District

\begin{tabular}{|c|c|c|c|c|c|c|}
\hline \multirow[t]{2}{*}{ Indicators } & \multicolumn{3}{|c|}{ Aban district } & \multicolumn{3}{|c|}{ JSC «Molokanovka» } \\
\hline & 2015 & 2016 & 2017 & 2015 & 2016 & 2017 \\
\hline Hourly labor productivity, rub. & 571.5 & 688.9 & 719.8 & 302 & 482.3 & 276.4 \\
\hline Growth rate of hourly labor productivity, $\%$ & - & 120.5 & 104.5 & - & 159.7 & 57.3 \\
\hline Increase rate of hourly labor productivity, $\%$ & - & 20.5 & 4.5 & - & 59.7 & -42.7 \\
\hline Hourly wage, rub. & 51.8 & 62.2 & 71.2 & 49.9 & 61.7 & 70,3 \\
\hline Growth rate of hourly wages, $\%$ & - & 120.1 & 114.5 & - & 123.6 & 113.9 \\
\hline Increase rate of hourly wage, $\%$ & - & 20.1 & 14.5 & - & 23.6 & 13.9 \\
\hline Increase rate in labor productivity to wage growth & - & - & 0.3 & - & & -3 \\
\hline
\end{tabular}

Economic tools (forecasting and planning, methods and tools for management of material and technical, financial, investment and innovation subsystem) determine the possible ways to maintain the proper state of management objects, reasoned ways of development of the system and methods of attracting resources for this. Include-wages and bonuses; sanctions for inadequate quality or quantity of work. One more barrier on the way to increase in productivity - rather low level of the salaries of Russians in comparison with other countries, and cheap work cannot be highly productive [4].

Motivational tools (a set of command-administrative and socio-economic incentives that encourage staff to work efficiently) - a set of tools, methods and forms of interest in achieving the best socio-economic results for management elements of the system. Among the variety of motivational tools, we can distinguish, for example, economic incentives (all types of rewards for the results of work) as well as motives, that is, internal attitudes and external influences [5].

Organizational tools include the regulation of the company's employees through the creation of internal regulations.

These tools together are ready to guarantee a balanced and efficient functioning of the organization. Each of these mechanisms should contribute to the ultimate goal in the management of the organization [6].

One of the main enterprise indicators is the efficiency of labor resources, which is characterized by indicators of labor productivity (table I).

From this table it can be seen that the number of employees decreases every year both in the district and at the enterprise. If we analyze the changes in labor productivity for the period 2015-2017 in the Aban district, we can see a tendency to increase the production of commodity products per 1 person by $35.5 \%$ [7].

Labor productivity per 1 employee and per 1 person - day, per 1 person - hour increases steadily during the study period by 23.7 and $25.9 \%$, respectively. This may be due to several reasons: the introduction of new technologies, so milking machines, new harvesters, etc.; stimulation of workers by increasing wages; reducing the number of workers, whereby the load per 1 person increases, etc.

Labor productivity in agriculture remains one of the most significant indicators of production efficiency. At the macro level, it indicates not only the effectiveness of the use of labor, but also it is one of the important indicators in determining the policy in the field of its payment. To some extent, the level of labor productivity may indicate the competitiveness of products $[8,9]$. The main in the study of labor productivity is the law of the ratio in the growth rate of labor productivity and wages. The essence of the law is that productivity growth should outpace wage growth. In this case, we can talk not only about the development of the enterprise, but also about its ability to stay "afloat" in crisis periods [10]. Next, consider the ratio of growth rates in labor productivity and wages in the studied objects (table II).

tendency of growth in labor productivity and its payment is noticeable. In 2017, hourly productivity increased by $4.5 \%$ compared to 2016. At the same time, the payment of 1 person per hour for the same period increased by $14.5 \%$. The increase in labor productivity by $1 \%$ of the increase in wages in the reporting year was $0.3[11,12]$. 
On JSC «Molokanovka» productivity per hour decreased by $57.3 \%$, the growth rate is negative. At the same time, the payment of 1 person per hour for the same period increased by $13.9 \%$. The increase of labor productivity to wage growth in the reporting year was -3 .

\section{DISCUSSION}

Acceleration of labor productivity in agriculture in modern conditions is an objective necessity and contains a significant economic importance in solving many financial and social problems. The key to productivity is to increase the production of gross agricultural output, which contributes to the fuller satisfaction of all food needs for the population of the country. Increasing labor productivity makes it possible to reduce the cost of payment in general and per unit of agricultural products $[11,13]$.

In modern economic conditions, the basis of labor productivity is the productive force of labor. The productive power of labor should be understood as the ability of an employee in specific conditions, circumstances to guarantee the achievement of a certain result [14]. The higher the productivity of living labor, the more the means of production are consumed. Thus, the labor productivity growth through reducing the volume of living labor relative to the volume set in motion the means of production, naturally reduces the unit cost of the product $[15,16]$.

A significant step in the analytical work at the enterprise is the search for reserves of labor productivity, the development of organizational and technical measures for the implementation of these reserves and the direct implementation of these measures [17].

There are many reserves for increasing labor productivity, but for a particular enterprise, the intra-production one is more acceptable, since the increase in labor productivity will occur by reducing the labor intensity of production and improving the use of working time at the enterprise $[18,19]$. At the same time, increasing productivity in the enterprise, as a rule, is achieved by several methods:

- Replacement of labor with capital (re-equipment of production, introduction of new equipment and technologies);

- Intensification of work (application of administrative measures aimed at accelerating the performance for employees of their work);

- Improving the efficiency of labor organization (identification and elimination of all factors leading to production losses, determination of rational ways to increase the efficiency of work) [7, 20].

\section{CONCLUSIONS}

Staffing is one of the main topics in the study of systemic problems in agricultural development. Staffing is of strategic importance in the formation of agriculture innovative potential [21]. Improving the level of technical equipment at the enterprises of the Aban district, including JSC "Molokanovka", is the material basis for productivity growth.
In this situation, technological progress, which is expressed in the increase of the number and quality of agricultural machines, is an important process of successive replacement of live labor by the work of the most active part of the fixed assets, which are machines and other equipment [22, 23].

In the process of production activities, many agricultural enterprises experience a constant short-term need for money in order to purchase raw materials, pay for fuel, provide respite to buyers, and stimulate workers to improve productivity. This requires working capital (own working capital), the importance of which for the economy is that it is considered one of the main sources of current needs coverage in the financing of current assets [24, 25]. Especially the beginning entrepreneurs and small farms which business plans do not attract credit institutions in connection with the low capitalization volume suffer from the funds unavailability $[26,27]$. It is also necessary for the growth of capital labor, as the main reserve to increase productivity in the studied enterprises, through the introduction of new technologies, varieties of crops, livestock breeds, and equipment in the production process.

The originality of this article is to identify tools for labor productivity management and factors that determine the level and dynamics of labor productivity growth in agriculture, analyze the current state of labor productivity at agricultural enterprises in the Aban district, and propose measures to improve labor productivity in the agricultural sector.

The authors summarized the theoretical bases of tools for labor productivity management, analyzed labor productivity indicators, and formulated the results.

\section{REFERENCES}

[1] O. V. Zinina, N. A. Dalisova, N. I. Pyzhikova and J. A. Olentsova "Development prospects of the Krasnoyarsk region agroindustrial complex in the export conditions", IOP Conference Series: Earth and Environmental Science, 23 August 2019, International Scientific Conference on Agribusiness, Environmental Engineering and Biotechnologies, AGRITECH 2019, Krasnoyarsk State Agrarian University Krasnoyarsk, Russian Federation, vol. 315, issue 2.

[2] K. Yu Burtseva, "Modern tools of enterprise management, personnel and labor productivity", Vector of science of Togliatti state University, 2012, no. 4 (22), pp. 223-228.

[3] T. V. Nazarchuk and O. M. Kostyuk, "Management of organizations: textbook", Kiev: Center of educational literature, 2018, 560 p.

[4] A. I. Popova, "On the issue of increasing labor productivity in Russia", Modern science-intensive technologies, 2014, no. 7, pp. 74-75.

[5] K. O. Krivolapova, "Analysis of labor productivity and assessment of the impact of individual factors on labor productivity", Financial, economic and technological problems of regional development: a collection of scientific papers on the materials of the International scientific and practical conference of young scientists, 2019, pp. 120 122

[6] V. A. Bereslavskaya, "Efficiency of labor resources use and optimization of labor remuneration", Economic analysis: theory and practice, 2008, no. 14, pp. 50-55.

[7] M. V. Potapenko and A. V. Sharopatova, "Labor productivity as a factor of increasing the efficiency of management at the enterprise", Epoch of science, 2016, no. 8, pp. 100-103.

[8] A. F. Serkov and B. C. Chekalin, "Labor productivity and competitiveness of agricultural products", Agrarian bulletin of the Urals 
[19] M. Yu. Kulikov and A. E. Khachaturov, "Management system as a limiting factor of labor productivity growth of Russian companies", Management in Russia and abroad, 2016, no. 1, pp. 15-25.

https://cyberleninka.ru/article/n/proizvoditelnost-truda-i-konkurento sposobnost-produktsii-selskogo-hozyaystva.

[9] M. G. Ozerova, A. V. Sharopatova, and J. A. Olentsova, "Improving the competitiveness of agricultural products as a basis for solving import replacement issues", IOP Conference Series: Earth and Environmental Science, 23 August 2019, International Scientific Conference on Agribusiness, Environmental Engineering and Biotechnologies, AGRITECH 2019, Krasnoyarsk State Agrarian University Krasnoyarsk, Russian Federation, vol. 315, issue 2.

[10] V. A. Bereslavskaya, "Efficiency of labor resources use and optimization of labor remuneration", Economic analysis: theory and practice, 2008, no. 14, pp. 50-55.

[11] M. V. Potapenko and A. V. Sharopatova, "Factors and ways of increasing labor productivity in agriculture", Innovative trends in the development of Russian science: materials of the $\mathrm{X}$ International scientific-practical conference of young scientists dedicated to the year of ecology and the 65th anniversary of Krasnoyarsk state agrarian university,. 2017, pp. 253-256.

[12] O. V. Zinina and J. A. Olentsova, "The mechanism of increasing the level of sales in credit institutions (banks)", Azimuth of Scientific Research: Economics and Administration, 2019, pp. 148-152.

[13] E. N. Klochkova, V. I. Kuznetsov, and T. E. Platonova, "Enterprise Economics", Moscow: Yurayt, 2014, 448 p.

[14] Agarkov A. P. Economics and management at the enterprise / A. P. Agarkov [and others]. Moscow: Dashkov \& Co., 2013. - Pp. 400

[15] R. A. Ershov, "Agricultural labor: you give productivity! Assessment of agricultural productivity", Russian entrepreneurship, 2009, no. 3-1, pp. 131-135.

[16] L. A. Afanasyeva, M. A. Menshikova, O. N. Pronskaya, A. V. Ryumshin, and V. N. Khodyrevskaya, "Formation of a balanced scorecard as an element of strategic personnel management in the organization", Economics and entrepreneurship, 2019, no. 1 (102), pp. 1061-1066.

[17] A. V. Belokopytov, "Reserves of agricultural labor productivity growth (on the example of agricultural enterprises. Smolensk region)", Economics of agricultural and processing enterprises, 2004, no. 4, pp. $10-12$.

[18] V. N. Besedina, "Productivity and efficiency of use", Moscow: INFRAM, 2012, 341 p.
[20] A. Ya. Kibanov, "Fundamentals of personnel management", Moscow: Infra-M, 2011, $201 \mathrm{p}$.

[21] D. V. Parshukov, N. I. Pyzhikova, D. V. Khodos, and E. Yu. Vlasova, "Evaluation and forecast of demand for labor force of the agrarian sector of economy (regional aspect)", Journal of Advanced Research in Law and Economics, 2017, T. 7, no. 7, 1812 p.

[22] M. A. Smirnov and O. M. Sannikov, "Productivity, wages and economic efficiency of labor", Standard of living of the population of regions of Russia, 2008, no. 2 (120), pp. 5-22.

[23] O. I. Antamoshkina, O. V. Zinina and J. A. Olentsova, "The optimization of business processes at the enterprises of agro-industrial complex", 19th International Multidisciplinary Scientific GeoConference SGEM 2019, Conference Proceedings, 2019 [Electronic resource]. Available at: www.sgem.org.

[24] A. V. Sharapatova and Zh. N. Shmeleva, "Management of cash flows in agricultural organizations", Azimuth of Scientific Research: Economics and Administration, 2019, V. 8, no. 3 (28). pp. 393-396.

[25] V. Mazloev and M. Ozerova, "Problems of spatial development of the Series: Earth and Environmental Science, 23 August 2019, International Scientific Conference on Agribusiness, Environmental Engineering and Biotechnologies, AGRITECH 2019, Krasnoyarsk State Agrarian University Krasnoyarsk, Russian Federation, vol. 315, issue 2.

[26] N. G. Filimonova, M. G. Ozerova, I. N. Ermakova, and N. B. Miheeva, "Crowdfunding as the way of projects financing in agribusiness", IOP Conference Series: Earth and Environmental Science, 23 August 2019, International Scientific Conference on Agribusiness, Environmental Engineering and Biotechnologies, AGRITECH 2019, Krasnoyarsk State Agrarian University Krasnoyarsk, Russian Federation, vol. 315, issue 2.

[27] A. V. Pozhkova, "The implementation capabilities of the brand commercial network on the regional market of pasta", IOP Conference Series: Earth and Environmental Science, 23 August 2019, International Scientific Conference on Agribusiness, Environmental Engineering and Biotechnologies, AGRITECH 2019, Krasnoyarsk State Agrarian University Krasnoyarsk, Russian Federation,vol. 315, issue 2. agro-industrial complex of the Krasnoyarsk Region", IOP Conference 